\title{
Effect of Additives on Maximizing Petrol Production from Crude Oil and Investigation of Properties
}

\author{
Md. Ashaduzzaman ${ }^{1, *}$, Md. Yunus Miah ${ }^{2}$ \\ ${ }^{1}$ Department of Applied Chemistry and Chemical Engineering, University of Dhaka, \\ Dhaka 1000, Bangladesh, \\ Tel: +880-2-9661900-73/7402, Fax: +880-2-8615583 \\ ${ }^{2}$ Institute of Fuel Research and Development, BCSIR, Dhaka 1000, Bangladesh \\ *E-mail address: azaman01@du.ac.bd
}

\begin{abstract}
The objectives of this work were concentrated to investigate the enhancement of petrol distillate production from crude oil after treating with two additives. Attempts were also made to find out the mechanisms, those are responsible for enhancing the quantity and quality of petrol from crude oil by straight run refining process. From this study, it has been illustrated that the yield of petrol was directly proportional to the lubricating oil and inversely proportional to the bitumen asphalt content in the hydrocarbon mixture influenced by both physical and chemical reasons. The yield of petrol was increased ca. $4 \%(\mathrm{w} / \mathrm{w})$ when $0.25 \%(\mathrm{w} / \mathrm{w})$ additive- 1 was used for blending before distillation. The physical properties of distillate petrol product were studied as well as the chemical quality was determined by TGA, ${ }^{1} \mathrm{H}$ - NMR and GC-MS photometer.
\end{abstract}

Keywords: petrol; crude oil; additive; quality; mechanism

\section{INTRODUCTION}

Distillation of crude oil for petroleum products is a crucial issue regarding to enhancement of distillate product. The demand of petrol has been increasing day by day due to increase the number of vehicles production for the modern civilization. Among the various techniques, catalytic cracking in presence of activating additives ${ }^{1-3}$ is an important technology to increase the distillate production. To meet the demand of unleaded gasoline the construction of new catalytic cracking or distillation and alkylation units have been established for increasing the yields of high-octane gasoline ingredients and on the exclusion of low-octane naphthas from gasoline blends ${ }^{4}$. Quality of the main product has also been found improved especially octane number of petrol.

Besides, quality of petrol is another concerning factor to the environmentalists because of global warming due to emission of huge green house gases as combustion products as well as metal particles in atmosphere. Determination of petrol quality considering physical properties and chemical compositions by several instruments has been done by many research groups ${ }^{5-7}$. Among these techniques, thermal analysis has been used in the last 30 years for studying the petroleum and petroleum products. For crude oil, the techniques were normally applied for studying the oils pyrolysis and combustion ${ }^{8,9}$. Thermo-gravimetry (TG) has been used to 
study the effect of the oil composition on the pyrolysis kinetic of the crude ${ }^{10-13}$. There are many profile production technology available for maximizing distillate production and quality $^{14}$ from crude oil which are very complicated and highly expensive to implement in practice specially in developing and under developing country. Therefore, in many circumstances by considering the "state -of- the- art" concept production technology can be changed slightly.

In this study, we implement a blending unit for mixing the crude oil and additives before charging in a distillation unit. The improvement of petrol quality has been proved by instrumental means. The mechanisms, which are responsible for recovery of high quantity and improved quality of petrol, are still unknown although we have elaborately discussed some clues that would be involved with the high recovery of improved quality of petrol by using different types of additives in the straight run refining process of crude petroleum.

\section{EXPEROMENTAL}

\section{1. Materials and methods}

The used crude oil was supplied by Eastern Refinery, Bangladesh. Lubricating oils (additive 1 was purchased from I. B. S. Associates, Aziz Chamber, 6 Jublee Road, Chittagong and additive 2 was purchased from GMS composite knitting industries ltd., Joydevpur, Gazipur) were used as activating additives.

Distillation: Distillation was carried out in a distillation system according ASTM D1160, Model: PETRODIST 300, Manufacturer: HARMANN PAULSEN. D-2000 HUMBURG 65, GERMANY. Well-stirred crude oil into a flask was weighed by a balance and then required quantity of additive was mixed. Then the whole apparatus was set up for carrying out the operation in atmospheric pressure up to $180^{\circ} \mathrm{C}$ to collect gasoline distillate.

Thermo gravimetric Analysis (TGA): Model: TGA-50, Manufacturer: SHIMADZU CORPORATION TESTING \& WEIGHING EQUIPMENT DIVISION, KYOTO, JAPAN

${ }^{1}$ H NMR analysis: ${ }^{1} \mathrm{H}$ NMR Spectra were recorded at $250 \mathrm{MHZ}$ on a Bruker AC250 instrument where $\mathrm{CDCl}_{3}$ and TMS were used as solvent and internal standard respectively.

GC-MS (Gas Chromatography and Mass Spectrometry): Model: GCMS-QP5050A, Manufacturer: SHIMADZU CORPORATION, JAPAN. The GCMS-QP5050A is a compact, high performance quadruple mass spectrometer.

\section{RESULTS AND DISCUSSION}

The used crude oil and additives were thoroughly investigated separately before running the experiment. The properties of crude oil are furnished in Table 1. One can easily speculate that the properties of crude oil are not unique. The content of carbon residue and sulfur were $6.6 \% \mathrm{w} / \mathrm{w}$ and $1.04 \% \mathrm{w} / \mathrm{w}$ respectively. The additives were analyzed by TGA and ${ }^{1} \mathrm{H}-\mathrm{NMR}$ spectroscopy precisely to define their chemical compositions. Table 2 presents the results of ${ }^{1} \mathrm{H}$ NMR of two additives. The experimental data shows that additive 1 contains lower amount of aromatic protons than additive 2 whereas, for paraffinic protons an opposite phenomenon is observed. Results of TGA analysis from fresh crude oil and additives 1 and 2 have been demonstrated in Table 3 . About $33.5 \% \mathrm{w} / \mathrm{w}$ of crude oil was obtained as gasoline fraction 
which was collected from the boiling point fraction 35 and $180{ }^{\circ} \mathrm{C}$. The additives contain a variety of heavy petroleum fractions with lubricating oil, paraffin wax and bitumen asphalt.

Table 1. Properties of crude oil

\begin{tabular}{|c|c|c|}
\hline \multicolumn{2}{|c|}{ Properties } & Values \\
\hline \multicolumn{2}{|c|}{ Density at $20^{\circ} \mathrm{C}, \mathrm{gm} / \mathrm{cc}$} & 0.8281 \\
\hline \multicolumn{2}{|c|}{ Specific gravity at $15^{\circ} \mathrm{C}$} & 0.85813 \\
\hline \multicolumn{2}{|c|}{ Water content,(V/V)\% } & 0.2 \\
\hline \multicolumn{2}{|c|}{ Pour point, ${ }^{\circ} \mathrm{C}$} & -27 \\
\hline \multicolumn{2}{|c|}{ Flash point, ${ }^{\circ} \mathrm{C}$} & 18 \\
\hline \multicolumn{2}{|c|}{ Fire point, ${ }^{\circ} \mathrm{C}$} & 22 \\
\hline \multirow{2}{*}{ Viscosity, cS } & at $40^{\circ} \mathrm{C}$ & 6.12 \\
\hline & at $100^{\circ} \mathrm{C}$ & 1.04 \\
\hline \multicolumn{2}{|c|}{ Carbon residue, mass $\%$} & 6.60 \\
\hline \multicolumn{2}{|c|}{ Sulfur content, mass $\%$} & 1.04 \\
\hline \multicolumn{2}{|c|}{ Calorific value, $\mathrm{Kcal} / \mathrm{Kg}$} & 10405.08 \\
\hline
\end{tabular}

Table 2. Type, name and ${ }^{1} \mathrm{H}$ NMR analysis of additives 1 and 2.

\begin{tabular}{|c|c|c|c|}
\hline Type & Name & $\begin{array}{c}\text { \% of aromatic } \\
\text { proton }\end{array}$ & $\begin{array}{c}\text { \% of paraffinic } \\
\text { proton }\end{array}$ \\
\hline Additive 1 & Lubricating oil & 1.474 & 98.526 \\
\hline Additive 2 & Lubricating oil & 1.801 & 98.199 \\
\hline
\end{tabular}

Figure 1 shows the variation of the yield of petrol from crude oil in presence of additives 1 and 2. The production of gasoline (petrol) increased dramatically from 28.88 to $32.84 \%$ (by wt.) when $0.25 \%$ (by wt. of crude oil) of additive 1 was charged. As further increased the addition of additives, the yield of petrol remained steady at about $31.5 \% \mathrm{w} / \mathrm{w}$ up to $1 \% \mathrm{w} / \mathrm{w}$. More than $0.5 \% \mathrm{w} / \mathrm{w}$ additive influenced to lower the production of petrol.

The critical concentration of additive for petrol production was revealed $0.5 \% \mathrm{w} / \mathrm{w}$. 
Table 3. Results of thermo-gravimetric analysis of fresh crude oil and different types of additives.

\begin{tabular}{|c|c|c|c|c|c|}
\hline Name & $\begin{array}{c}\text { Temp. } \\
{ }^{\circ} \mathrm{C} \\
\end{array}$ & $\begin{array}{c}\text { Carbon } \\
\text { No. } \\
\end{array}$ & $\begin{array}{c}\text { Fresh Crude } \\
\text { oil }\end{array}$ & A1 & $\mathbf{A 2}$ \\
\hline L.P. Gas & Up to 35 & $\mathrm{C} 1-\mathrm{C} 4$ & 0.795 & --- & --- \\
\hline Light naphtha & $60-110$ & $\mathrm{C} 6-\mathrm{C} 7$ & 13.063 & --- & --- \\
\hline Gasoline & $35-180$ & $\mathrm{C} 5-\mathrm{C} 12$ & 33.432 & --- & --- \\
\hline Diesel & $180-350$ & $\mathrm{C} 13-\mathrm{C} 18$ & 47.881 & 17.640 & 21.845 \\
\hline-- & IBP-270 & $\mathrm{C} 5-\mathrm{C} 18$ & 61.421 & 1.723 & 2.429 \\
\hline Lubricating oil & $270-400$ & $\mathrm{C} 15-\mathrm{C} 18$ & 28.899 & 51.893 & 58.575 \\
\hline Paraffin wax & $>400$ & $\mathrm{C} 18-\mathrm{C} 30$ & 9.484 & 45.606 & 37.617 \\
\hline Bitumen asphalt & Residue & C30-above & 0.196 & 0.778 & 1.253 \\
\hline
\end{tabular}

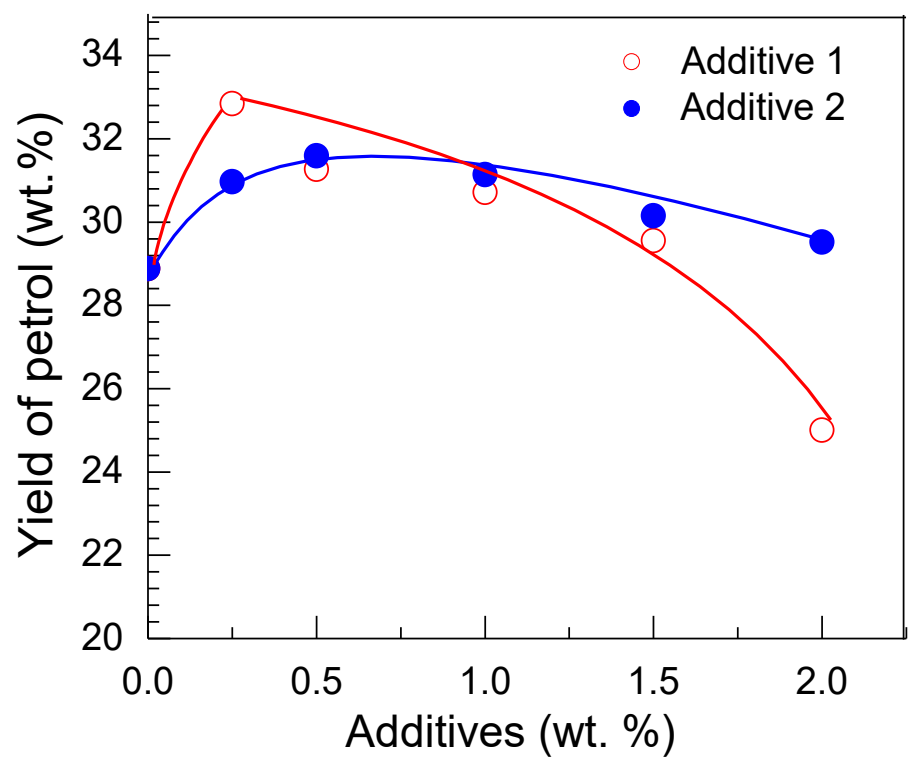

Fig. 1. Influence of the variation of additives on the yield of petrol obtained by atmospheric-vacuum distillation of crude oil in presence of additives 1 and 2.

Table 4 shows the fractional $(\% \mathrm{w} / \mathrm{w})$ distillation of crude oil containing $0.25 \% \mathrm{w} / \mathrm{w}$ of additives 1 and 2 . It was observed that $50 \% \mathrm{w} / \mathrm{w}$ of crude oil was escaped approximately at 261 and $245{ }^{\circ} \mathrm{C}$ in presence of additive 1 and 2 respectively. Effect of additives on changing the boiling point of crude oil reflects the change of physio-chemical properties upon which 
the quality and quantity of petrol production depend. The percentages of light and heavy fractions present in crude oil would be easily distinguished from this data.

Table 4. Fractional distillation of crude oil with $0.25 \%$ (by wt. of crude oil) additives $1 \& 2$.

\begin{tabular}{|c|c|c|}
\hline $\begin{array}{c}\text { Fraction, } \\
\text { \% by wt. }\end{array}$ & $\begin{array}{c}\text { Crude oil with A1 } \\
\text { Temperature, }{ }^{\circ} \mathbf{C}\end{array}$ & $\begin{array}{c}\text { Crude oil with A2 } \\
\text { Temperature, }{ }^{\circ} \mathbf{C}\end{array}$ \\
\hline 0 & 26.09 & 38.20 \\
\hline 10 & 125.88 & 114.04 \\
\hline 20 & 166.38 & 151.38 \\
\hline 50 & 261.15 & 244.49 \\
\hline 70 & 327.82 & 308.89 \\
\hline 90 & 427.04 & 407.62 \\
\hline 99 & 729.94 & 616.52 \\
\hline
\end{tabular}

Table 5 represents the data of ${ }^{1} \mathrm{H}$ NMR analysis. The results demonstrated that, as the additives were added incrementally with crude oil, the amount of aromatic protons gradually increased and the amount of paraffinic protons decreased. Besides, the amount of $1^{\circ}, 2^{\circ} \& 3^{\circ}$ paraffinic protons and protons of methyl groups $\left(-\mathrm{CH}_{3}\right)$ attached with the benzene ring structures were also increased with the increase of additive 1 . It is revealed that $6.121 \%$ protons of methyl groups $\left(-\mathrm{CH}_{3}\right)$ attached with the benzene ring structures present in petrol obtained from crude oil containing $1 \%$ (by wt. of crude oil) additive 1 . The increase of paraffinic $\left(-\mathrm{CH}_{3}\right) \&$ aromatic $(-\mathrm{CH}=)$ protons boost up the $\mathrm{O}$. N. of petrol produced from crude oil treated with additive 1 and can be estimated from the following empirical equation.

Table 5. Results from ${ }^{1} \mathrm{H}$ NMR spectra of petrol obtained from fresh crude oil and crude oil with additive 1 in different percentages.

\begin{tabular}{|c|c|c|c|}
\hline Name & $\begin{array}{c}\text { Petrol obtained } \\
\text { from fresh crude oil }\end{array}$ & $\begin{array}{c}\text { Petrol obtained from } \\
\text { crude oil with 0.25 \% } \\
\text { A1 }\end{array}$ & $\begin{array}{c}\text { Petrol obtained from } \\
\text { crude oil with 1 \% A1 }\end{array}$ \\
\hline $\begin{array}{c}\text { Aromatic } \\
\text { protons }\end{array}$ & 3.457 & 3.910 & 6.950 \\
\hline $\begin{array}{c}\text { Paraffinic } \\
\text { protons }\end{array}$ & 96.543 & 96.090 & 93.050 \\
\hline \multicolumn{2}{|c|}{$(\%$ by wt. of crude oil $)$} \\
\hline
\end{tabular}

O. $\mathrm{N}($ Octane Number $)=71+0.48\left(\mathrm{H}_{\mathrm{A}} \%\right)+1.02\left(\mathrm{H}_{\mathrm{B}} \%\right)+2\left(\mathrm{H}_{\mathrm{F}} \%\right) / 3\left(\mathrm{H}_{\mathrm{E}} \%\right)$

where, $\mathrm{H}_{\mathrm{A}}-$ aromatics protons, $\mathrm{H}_{\mathrm{B}}-$ olefinic protons, $\mathrm{H}_{\mathrm{F}}-$ paraffinic $1^{\circ}$ protons and $\mathrm{H}_{\mathrm{E}}-$ paraffinic $2^{\circ}$ protons. 
Table 6 shows the results of TGA of petrol. The variation of the fraction ( $\%$ by wt.) of produced petrol with respect to the gradual addition of additive 1 is very important to discuss. It is evident that when $0.25 \%$ additive was added then L. P gas, light petroleum gas and light naphthas were increased with respect to the product obtained from without and with $1 \%$ (by wt. of crude oil) of additive. It is well established that the lighter fractions of petroleum have average higher octane number.

Table 6. Results of thermo-gravimetric analysis of petrol obtained from fresh crude oil and crude oil containing $0.25 \%$ and $1 \%$ (by wt. of crude oil) additive 1.

\begin{tabular}{|c|c|c|c|c|c|}
\hline Name & $\begin{array}{l}\text { Temperatur } \\
\text { e range, }{ }^{\circ} \mathrm{C}\end{array}$ & $\begin{array}{c}\text { Carbon } \\
\text { No. }\end{array}$ & $\begin{array}{l}\text { Petrol from } \\
\text { fresh crude } \\
\text { oil. }\end{array}$ & $\begin{array}{c}\text { Petrol from crude } \\
\text { oil with } 0.25 \% \\
\text { A1 }\end{array}$ & $\begin{array}{c}\text { Petrol from } \\
\text { crude oil with } 1 \\
\% \text { A1 }\end{array}$ \\
\hline L.P. gas & up to 35 & $\mathrm{C} 1-\mathrm{C} 4$ & 4.668 & 8.916 & 4.830 \\
\hline L. P. gas* & $35-60$ & C5 - C6 & 12.216 & 20.629 & 13.472 \\
\hline $\begin{array}{c}\text { Light } \\
\text { naphtha }\end{array}$ & $60-110$ & $\mathrm{C} 6-\mathrm{C} 7$ & 46.519 & 67.046 & 52.214 \\
\hline Gasoline & $35-180$ & $\begin{array}{l}\mathrm{C} 5- \\
\mathrm{C} 12\end{array}$ & 94.667 & 88.756 & 94.717 \\
\hline Kerosene & $>180$ & $\begin{array}{l}\text { C12- } \\
\text { C15 }\end{array}$ & 0.665 & 2.328 & 0.453 \\
\hline \multicolumn{6}{|c|}{ *Liquefied petroleum gas } \\
\hline
\end{tabular}

In the Total Ion Chromatogram (Fig. 2) of petrol obtained from fresh crude oil, it is revealed that 31 peaks were analyzable. Retention time for the first peak was 1.953 min, mass spectrum of this (first) peak was $95 \%$ similar with 2-methylbutane and 31 number pear was tridecane, its emperical formula is $\mathrm{C}_{13} \mathrm{H}_{28}$. It is predicted that petrol obtained from fresh crude oil contained hydrocarbons having carbon number $\mathrm{C}_{5}-\mathrm{C}_{13}$.

The mass spectrums of peak no.14 and peak no. 29 were compared with their similar mass spectrums of known compounds respectively. From this phenomenon, it is clear that the peak no. 14 is 2,4-dimethyl hexane shows the base peak 43 and mass peak 114, which are 97 $\%$ similar with the mass spectrum of 2,4-di-methyl hexane and the peak no. 29 is $n$ - undecane shows the base peak 57 and mass peak 156 which are $96 \%$ similar with the mass spectrum of $n$-undecane. Total Ion Chromatogram of petrol obtained from crude oil containing $0.25 \%$ (by wt. of crude oil) of additive 1 is presented in Fig. 3.

There are 38 detectable peaks were revealed in the Figure 3. It is revealed that the first and the last peaks are 2-methyl butane and $n$-dodecane respectively. It is also remarkable that the petrol contains hydrocarbons having carbon number $\mathrm{C}_{5}-\mathrm{C}_{12}$.

The mass spectrum of peak number 12 and peak number 23 are compared with their similar compounds respectively. Spectrums of cycloheptratriene are $93 \%$ similar with the spectrum of 1,3,5 - cycloheptatriene where base peak is 91 and parent peak is 92 . 


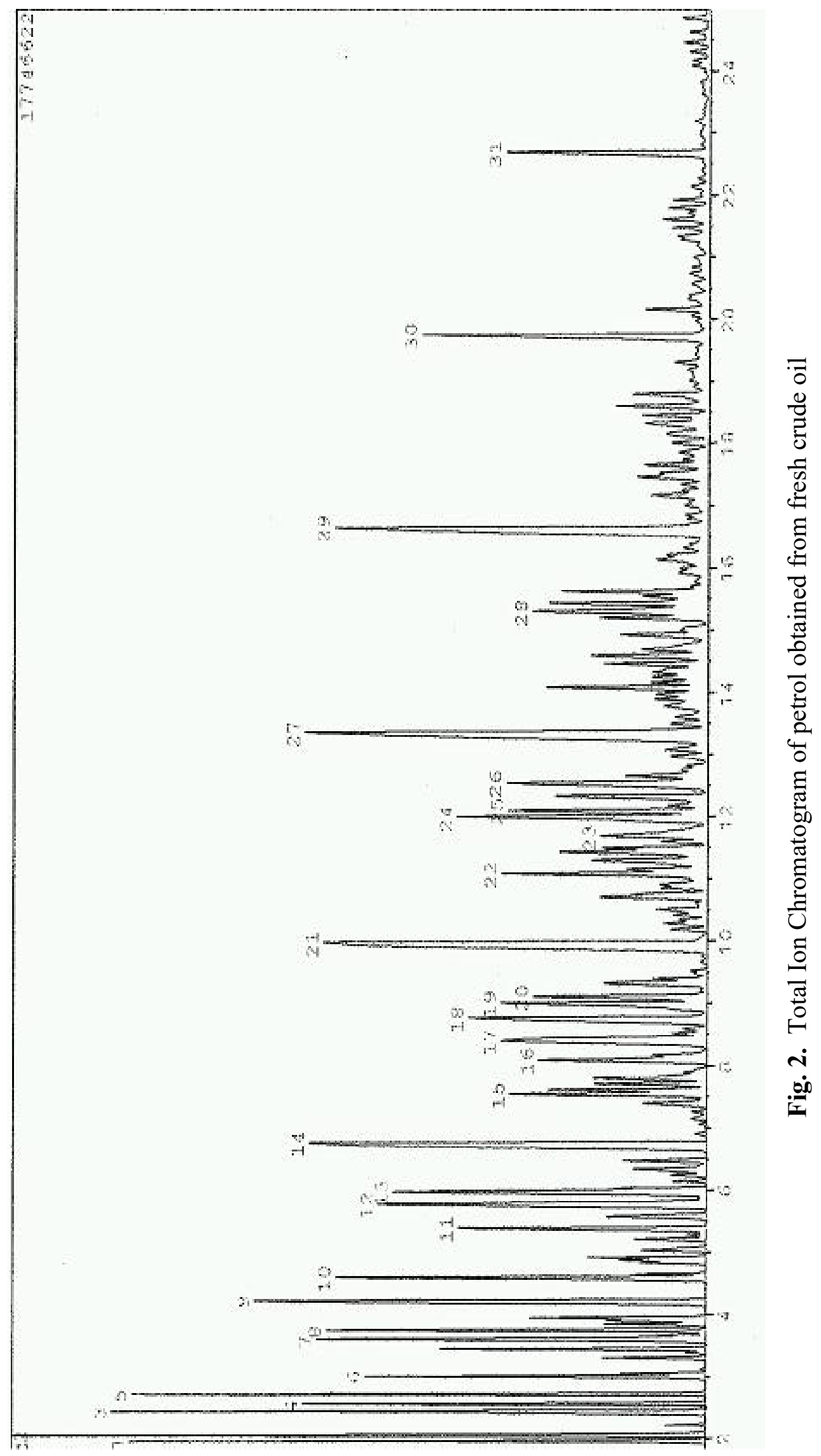




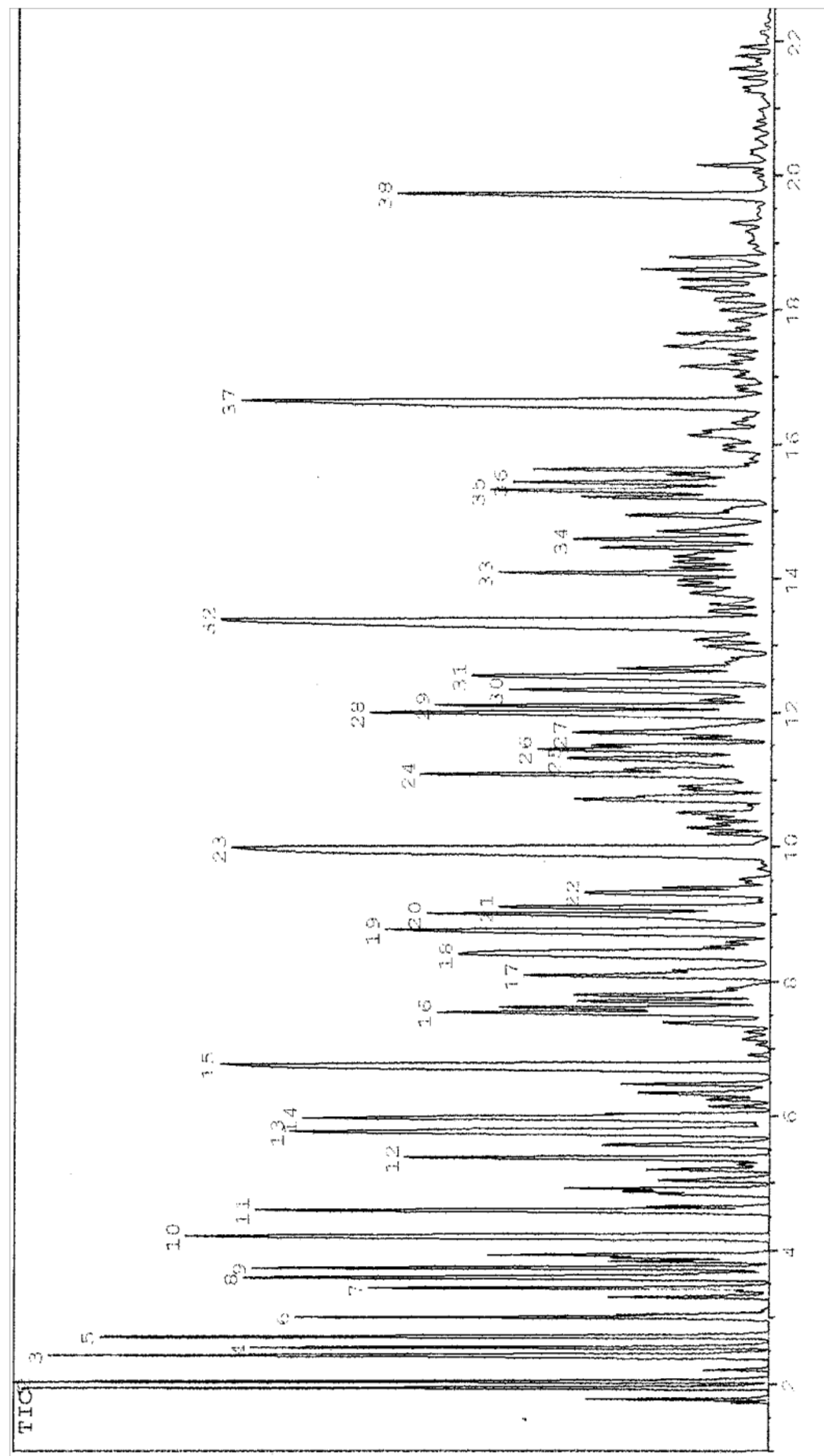

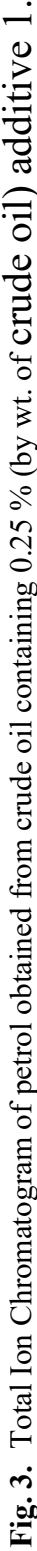


Table 7. Summarized results of GCMS for petrol.

\begin{tabular}{|c|c|c|c|c|}
\hline Product name & $\begin{array}{c}\text { \% of } \\
\text { n-Paraffins }\end{array}$ & $\begin{array}{c}\text { \% of } \\
\text { iso-Paraffins }\end{array}$ & $\begin{array}{c}\text { \% of } \\
\text { aromatics }\end{array}$ & $\begin{array}{c}\text { \% of cyclo- } \\
\text { compounds }\end{array}$ \\
\hline Petrol from fresh crude oil & 36.7 & 43.15 & 11.77 & 8.37 \\
\hline $\begin{array}{c}\text { Petrol from crude oil } \\
\text { containing 0.25\% additive 1. }\end{array}$ & 30.23 & 45.97 & 12.98 & 10.34 \\
\hline
\end{tabular}

Table 8. Fractionation of iso-paraffins.

\begin{tabular}{|c|c|c|}
\hline Product name & $\begin{array}{c}\text { Light iso-paraffins (up to } \\
\text { 2, 4-dimethylhexane), \% }\end{array}$ & $\begin{array}{c}\text { Heavy iso-paraffins (after } \\
\text { 2,4-dimethyl hexane), \% }\end{array}$ \\
\hline Petrol from fresh crude oil & 28.72 & 14.43 \\
\hline $\begin{array}{c}\text { Petrol from crude oil } \\
\text { containing } 0.25 \% \text { of A1 }\end{array}$ & 18.9 & 27.07 \\
\hline
\end{tabular}

Finally, it is revealed from Table 7 and 8 GC-MS results that the percentage of isoparaffins, aromatics and cyclocompounds were increased whereas, the percentage of $n$ paraffins in petrol was decreased when crude oil was blended with $0.25 \%$ (by wt. of crude oil) of additive 1. Furthermore, the percentage of light iso-paraffins decreases and heavy isoparaffins increases in petrol obtained from crude oil containing $0.25 \%$ (by wt. of crude oil) of additive 1 is shown in Table 8.

In crude oil additive acts as gum inhibitors for the light petroleum distillate. The most of them are phenolic, amino and sulfur compounds. Substances containing metals are recommended occasionally for the same purpose but they do not seem to be true oxidation inhibitors and their action might depend on immunizing metals dispersing the sludge and other causes. Asphaltic materials form colloidal solutions in light petroleum fractions and are the probable emulsifying agents in crude oils. This is indicated by the fact that the dilution of a crude oil emulsion with a light petroleum fraction, light gasoline tends to stabilize the emulsion.

Two antagonistic forces exist at the emulsion interface. Surface tension encourages the coalescence of the dispersed particles while the film of the emulsifying agent discourages coalescence. The stability of the emulsion depends on the relative magnitude of the two opposing forces. The emulsion can be broken by increasing the surface tension at the interface. Additives can take part into an intermolecular reaction with the hydrocarbons of crude oil. One can easily assumed that the contents of lubricating oil, paraffin wax and bitumen asphalt in the mentioned additive may have the decisive effect on the distillation process of crude oil for recovery of high quantity and improved quality of gasoline. To find out the confirm mechanism further study is also needed.

The reason behind the improvement of petrol quality was some light iso-paraffins were converted into heavy iso-paraffins. It is evident that $1^{\circ}\left(-\mathrm{CH}_{3}\right)$ and $2^{\circ}\left(-\mathrm{CH}_{2}-\right)$ protons were substantially decreased but $3^{\circ}$ protons $(-\mathrm{CH}=)$ were increased therefore, that some $n$-paraffins 
were changed into iso-paraffins by isomerization and addition reactions. The increase of aromatic compounds in petrol indicates the enhancement of petrol quality in terms of especially octane number.

Effect of additives on crude oil for diesel production by vacuum distillation will be discussed in future.

\section{CONCLUSIONS}

The demand of petroleum products especially, in transport sector has been increasing day by day due to the rapid industrialization and urbanization. To fulfill this demand, i.e. to get sufficient quantity of middle distillate and pollution free fuel, development of petroleum refining is essentially important.

In this work, a method has been developed for improving the straight run refining process. It is established that the yield of petrol increases from $28.88 \%$ to $32.84 \%(\mathrm{w} / \mathrm{w})$ when optimum quantity $0.25 \%$ (by wt. of crude oil) of additives 1 is used. Maximum quantity of additives depends upon the type of additives that's why optimum quantities of additives used in this process of distillation are different for different additives. By TGA, ${ }^{1} \mathrm{H}$ NMR and GCMS analysis, it is demonstrated that the quality of products (octane number of gasoline) which mainly depend upon the fractions of iso-paraffins and aromatics hydrocarbons also improved when optimum quantity of additive 1 is used.

This method mainly gives the opportunity to petroleum refiners to get their desirable quantity of petrol on the one hand and improve the quality of the products on the other hand.

To explain the total mechanism involves in this process, further study is also needed. For implementing the technology, no change of existing technique of refinery is necessary; a small arrangement for mixing the crude oil and additives is needed before the distillation operation.

\section{References}

[1] M. Miah Yunus, Technol. Topl. Acel. USSR 3 (1989) 10-13.

[2] N. A. Koval Chuk, M. Yunus Miah, Nefteperepab. Nefttekhi 10 (1989) 5-7.

[3] M. Miah Yunus, D.Sc. thesis (1992) 235.

[4] Encyclopedia of Britanica, $6^{\text {th }}$ edition, New York, 1994-2000.

[5] S. Husain, S. N. Alvi and R. R. Nageswara. Analyst 116 (1991) 405-408.

[6] R. Dhole Vivek, G. K. Ghosal, Journal of Liquid Chromatography 18(12) (1995) 2475-88.

[7] M. Miah Yunus, B. M. Aliev, A. I. Gasanov, Neft Gaz. USSR (1-2) (1992) 46-48.

[8] J. H. Bae, Soc Pet Eng AIME (1972) 211-219.

[9] M. V. Kok, M. R. Pamir, J Anal Appl Pyrol 35(2) (1995) 145-56.

[10] A. Ciajolo, R. Barbella, Fuel 63(5) (1984) 657.

[11] M. Ranjbar, G. Pusch, J Anal Appl Pyrol 20 (1991) 185-96 
[12] O. Karacan, M. V. Kok, Energy Fuel 11 (1997) 385-91.

[13] O. Karacan, M. V. Kok, Journal of Thermal Analysis 52 (1998) 781-8.

[14] J. Black, J. Petrunia, T. R. Powell, Petroleum Technology Qarterly 3(2) (1998) 65-70. 